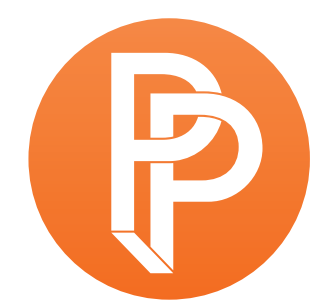

PERFORMANCE

PHILOSOPHY

\title{
BEING INCRISIS: SCENES OF BLINDNESS AND INSIGHT IN TRAGEDY
}

\author{
KATE KATAFIASZ NEWMAN UNIVERSITY
}

Flectere si nequeo superos, Acheronta movebo.

If I cannot deflect the will of heaven, then I shall move the river Acheron.

(Virgil qtd. in Freud [1899] 1997, 1)

\section{Staging crisis}

This investigation of crisis in ancient tragedy begins, appropriately enough, at the Theatre of Dionysus, to explore how the prototypical theatre space involved its audiences aesthetically in very particular ways. In the city beyond the theatre, citizens look and are looked-at, speak and listen. But as soon as we cross the first boundary to enter the auditorium, the social gaze leaves us; the auditorium becomes a space of public privacy because each person's gaze is subtly guided away from the other, and onto the performance space below, by 'open sight lines [which] converge from every angle on the huge uncluttered orchestra and what lay beyond it' (Gould 1989, 11).

The same architectural features that focus the audience gaze amplify the performers' voices with the acoustics of the megaphone, which famously allow a single actor to be audible at the back of the auditorium. So the theatre's second boundary between stage and auditorium not only delimits the lives of the citizens in the auditorium from the fictional situation inhabited by the dramatis personae of the play they are watching, but it also carefully separates and articulates the active and receptive functions of the gaze and voice. The audience give their gaze and receive the voice in one direction; while the performers give their voice and receive the gaze in the other. This phenomenon 
may shed light on what was for the Greeks a vital relationship between drama and democracy. These dramatic-democratic-aesthetics give each side-stage and auditorium, fiction and real life-physical dominion over, and at the same time exposure to, a different aspect of the other's sensory or ontological being. Interestingly, gaze and voice form the components of Lacanian desire $(2006,692)$, suggesting a structural relationship between drama and desire that will bear fruit later in this article in several ways. Indeed, it is the theatre's third boundary that may have been most instrumental in this respect, because the stage/backstage threshold, or skene, mediates between the fictional situation and the city in which it is staged most directly. In terms of circulating audience desire, it is the skene that stretches the relationship between gaze and voice most dramatically. The skene comes into play during the critical phase of the drama that is under particular investigation here: when violent events are indicated offstage. Gould tells us that behind the skene at the Theatre of Dionysus there was a backstage space, which

\begin{abstract}
served as a store-room for masks, costumes, and props, and as a green room for actors preparing to make their entrances. But by the early 450 s at least the skene is thought of as bounding the scene of action and in certain moments part of it [...] violent death characteristically occurs within, that is, inside the skene, and has its dramatic impact through the death-cries of the victim and the controlled passion of the messenger speech. $(1989,11,13)$
\end{abstract}

At such critical moments the eye cannot penetrate the skene; but the ear can, to afford audiences an intimate imaginative engagement with the fictional events taking place behind it. So when Simon Critchley asks: 'And what exactly is the pleasure we take in spectacles of pain?' $(2017,38)$, it may be useful to note that for the Greeks there were no such spectacles. The skene meant that violent death was not usually visually available to audiences. With regard to what Critchley calls tragedy's 'ghostly porosity of the frontier separating the living from the dead' (37), the reader's attention is drawn here to the fact that both aspects of the third boundary or skene can be activated by the drama: its painted surface and its blind side.

It may be worth observing at this point that one way to think of the innovations of the twentiethcentury theatre is in terms of dismantling these three dramatic thresholds. For instance, Augusto Boal's Invisible Theatre dispensed with the boundary between city and auditorium. Boal took the stage to the street, producing performances in public spaces that privileged dramatic actions to the extent that they were to be mistaken for actual events. Antonin Artaud abolished the second boundary between the stage and the auditorium and replaced it 'by a single site without partition or barrier of any kind' ([1932] 1986, 61). Although audiences in this situation know they have crossed the first boundary from street to performance space, without an auditorium they may momentarily experience a sort of hallucinatory uncertainty as to whether the events that pass before them are real or imagined. Bertolt Brecht's famous 'street scene' ([1945] 1986) brought street to stage in a way that privileged the aesthetics of the street; dramatic action was to be constantly interrupted by reportage and explanation; death cries and messenger speeches were no longer separated by a skene. 
The relationship between structure and crisis would appear paradoxical, which may be why the Modernists, seeking radical change, attacked these prototypical theatre aesthetics. Structure lets us know where we are, while crisis is flux and disorientation. As Critchley puts it: 'In play after play of the great tragedians (Aeschylus, Sophocles, Euripides), what we see are characters who are utterly disorientated by the situation in which they find themselves' (26). It is my proposal here that the skene is a structure that precipitates crisis; that the Oedipal metaphor of blindness as insight may have been intended to impact not just the tragic characters as Critchley has it, but also their audiences; that at key moments of dramatic crisis, play and skene seem to restrict the visual range of their audience, disorienting them alongside the fictional protagonists; and that such restrictions constitute a vital part of the critical function of Greek tragedy.

\section{Thinking through crisis}

We can elucidate this proposed relationship between skene, crisis, and critical thought further if we investigate two key terms used by Socrates in Plato's Republic to describe a journey down to the sea at Piraeus and back up to Athens. According to Jacob Howland,

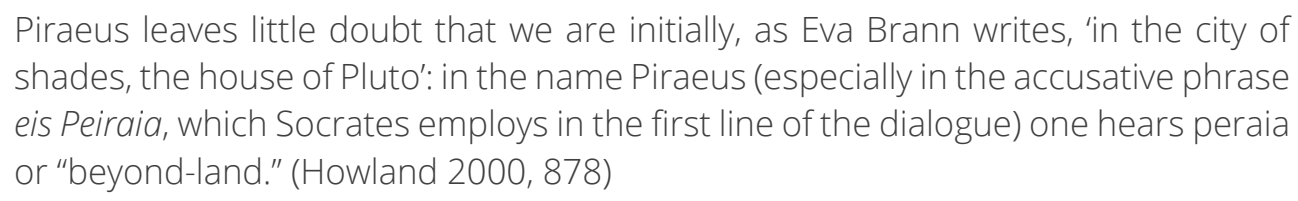

Howland suggests that the themes of descent and ascent, or katabasis and anabasis, are echoed several times in the Republic involving Gyges' ring of invisibility in book 2, the famous cave image of education in book 7, and the myth of Er in book 10, which sees Er's katabatic descent into Hades and anabatic return to consciousness on his funeral pyre at daybreak. Movement 'from the land of the dead to the land of the living, from darkness to light and from confusion to clarity' is reflected in the Odyssey, and in the Republic, where Socrates is depicted as a philosophical Odysseus. Xenophon went on to write about his own Anabasis, a military adventure interwoven with his own ascent to self-knowledge (Howland 2000, 878). As Luce Irigaray notes, in Plato's cave image of education critical thought moves from the blind cavern, via the speaking 'world', to the 'good', a place of insight. In Irigaray's terms and with her emphasis, the movement is 'uni-directional'-i.e. it ascends in Socratic terms anabatically, from darkness to light, confusion to clarity. For Irigaray, this Platonic move creates a 'blind spot' preventing 'intercourse' between the sensible (maternal 'cave') and the intelligible (paternal 'good'), except where language (culture) mediates between them (Whitford 2006, 109). But we can see from Socrates and Xenophon that crisis, or katabasis, is an important constituent of the ascent to anabatic self-knowledge, something the Platonic move would appear to erase. It is the wager of this paper that we can view the use of the skene in tragedy as a way to short circuit Plato's arrangement; the paper will investigate how tragedy's katabatic move from the painted to the blind side of the skene may conflate blindness and insight, body and intellect, to call culture to account. 
Euripides' Herakles ([C416BCE] 1997) offers interesting instances of the porous skene. As with much ancient drama, the action initially takes place on the street outside the palace. As the play's crisis intensifies its action shifts by degrees inside the palace, where it cannot be seen by its audience, to re-emerge later as the extent of the catastrophe becomes apparent. It may help the reader to visualise the dramatic short-circuit I am proposing here if we view the theatre, the play being staged, and Plato's cave analogy as palimpsests of each other. In this scenario the backstage obscene space/palace interior corresponds with Plato's blind cave; the stage/street outside the palace corresponds with Plato's world; while the auditorium is a place of potential insight. Onstage, words and images synchronise to show and tell us the play's fictional events in a space which mediates between the obscene/cave and the 'good' insightful auditorium.

Herakles begins the play off-stage in Hades, having failed to return from his labours there. His unprotected family are about to be slaughtered by usurping King Lykos. Herakles' wife Megara has bought a little time for her children by persuading Lykos to let her back into the palace to dress them properly for sacrifice. This movement behind the skene confers invisibility and can be said to be katabatic; in this sense the skene would seem to mirror the river Charon, tributary to the Styx, in its function as a boundary between life and death. Megara and her children re-emerge alive, but ominously dressed for death and on borrowed time. Two parados at the sides of the stage and the palace doors in the middle of the skene penetrate its invisibility, but it is usually only the characters in the play who can 'see' into the imagined world beyond. These entrances give the boundary scope to flex and shift. For instance, when Megara glimpses Herakles in the parados, she says she thinks she is 'seeing things' (I. 519). But Herakles' trajectory back from Hades is anabatic; he is not a ghost or shade from the underworld. Herakles enters and is quickly appraised of the horror of his family's situation. He says of his children:

All they had was my name,

And they were to die for that. (1. 578-9)

Words are then made flesh; Euripides equips Herakles with striking metaphors that conjure dramatic actions and images to define him tangibly as a kind and loving husband and father. The words that follow cannot fail to give substance to Herakles' heroic reputation: his children literally cling to him.

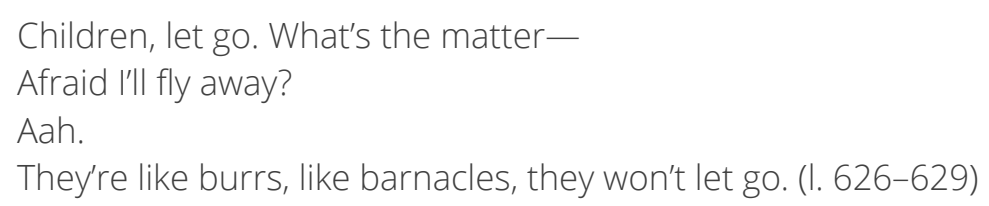

These metaphors are strikingly ekphrastic. If a name alone means death to the children, the subsequent staged collaboration of word, image, and action conjures a poignant liveliness with which the audience may relate on many levels: the modalities of eye and ear illuminating each other to produce the vivid illusory mimesis that so worried Plato. Here, the soon-to-die meet the 
resurrected and we are likely to be emotionally affected by the powerful corroboration of word and image. Critchley unearths evidence that ancient audiences of tragedies did indeed find emotional consolation; he posits: 'We might say that tragedy consoles through an imaginative enthrallment with an almost trance-like, other-worldly state that is linked, for Timocles and Aristotle and us, to pleasure, hedone' $(2017,37)$. But such anabatic moments of mimesis do not last long in tragedy and serve only to set the stage so that their tragic reversal will have more impact. When the blind side of the skene is activated in crisis, obscene events we hear but cannot see will take place behind it, and word and image will fail to corroborate or 'ground' each other. Without semblance, such moments are far from mimetic; their blinding, de-centring, katabatic impact on their audience, hardly entrancing or pleasurable.

Crisis soon returns and with it, uncertainty for Herakles' audience. Herakles, Megara and the children go inside the palace, bait for an unsuspecting Lykos, who soon reappears. In front of the skene, Amphitryon, Herakles' step-father, tells Lykos he can see Megara and the children on their knees praying inside the palace; if Lykos wants to slaughter them he will have to go inside and do it there. This reported-and from the auditorium, visually uncorroborated-'view' behind the skene into an otherwise unrepresented imagined world functions technically like the parados as we have seen; ghosts, hallucinations, and now lies, stalk this inchoate zone. So, with this second activation of the blind side of the skene begins the critical phase of the drama in earnest. As the action of the play moves into the obskene, even the chorus in front of the skene will be as blind as we. We may wait for the pleasure of hearing Lykos unexpectedly encounter the might of Herakles inside the palace. Simon Critchley claims that 'tragedy requires some degree of complicity on our part in the disaster that destroys us' $(2017,31)$. In Herakles, I suggest that the pleasure of waiting for Lykos and Herakles to meet implicates the audience in the murderous events that follow, making us jointly responsible with the protagonist for his fate.

The fact that news of the encounter between Lykos and Herakles reaches us in a range of different auditory modalities makes our collusion even more difficult to shake off: if 'shame lies on the eyelids' as Critchley has it (33), 'the ears have no lids' according to Lacan (in Dolar 2006, 78). Lykos' incoherent death cries sound through the skene; a servant's voice tells us this is 'the song we longed for' (I. 753); then Lykos himself becomes intelligible, crying: 'Thebans! Help me! Help me!' (I. 757-8). But it is his silence, auditory equivalent of blindness, that pronounces him dead; as the chorus puts it: 'Listen! Nothing' (I. 760). Then they step in with a celebratory song and dance. If crisis interrupts the powerful gaze of the audience, it renders the commanding voice of the stage wordless; we are caught between word and voice, then sound and silence, as words and then bodies fail. The blind side of the skene would seem to be activated intensively for its audience by this deathly silence, but only momentarily; their eye and ear are soon in synch again, the anabatic pulse of the stage restored, as the chorus sing and dance.

The next iteration of crisis follows swiftly, with a katabatic reversal or peripety. The choral song and dance is interrupted by the appearance of two immortals atop the skene. Madness, Night's daughter, and Iris, God's messenger, terrify the chorus, whose music disintegrates into a speechless cry: 'e-a, e-a' (I. 813). Madness and Iris announce that since Herakles is Zeus's illegitimate 
son, they have been sent by Zeus' jealous wife Hera to drive him mad so that he will kill his own family. As Madness goes inside to stalk Herakles, she makes us privy to her own blinding technique: 'He can't see me now, but see! He's mine!' (I. 873). Words fail the chorus, who cry: 'Otototoee' (I. 874), regaining the power of speech to tell us they can see madness riding and goading Herakles inside the palace. Soon we hear Amphitryon similarly caught between voice and word in horror: 'Eeoh moee. Help us!' (I. 885). For a while, from line 886 to line 898 , we do not know what is happening inside the palace. The chorus tells us they hear sounds like treading grapes, which they think may be 'stamping blood'; they report thudding music, pounding horns and shrieking flutes, inferring the horrific notion that Herakles is hunting down his own children in sport. This speculative commentary on the cacophony going on inside is itself cut short: the roof breaks and there is a huge shriek from inside the palace.

\section{Psychoanalysing crisis}

Let us put the tragedy of Herakles on pause at this point to propose that in crisis, whether dramatic or otherwise, we depart from the comforts of language and of semblance, and so from representation and mimesis, to enter what Lacan terms the register of the real. We have already noted how, on entering the Theatre of Dionysus, audiences cross the first boundary between the street and the theatre, which choreographs their gaze to focus on the stage below; how the second boundary, which demarcates stage from auditorium, choreographs the performing voice. In this way the prototypical theatre space distributes Lacanian desire, the active and receptive functions of gaze and voice, equitably; the auditorium gives the gaze and receives the voice, while the stage gives the voice and receives the gaze. While the play's action takes place in front of the skene in the proskene, in view of the audience, these democratic dynamics pertain. But when the action crosses beyond the skene at the third boundary as it does in crisis, the powerful audience gaze is thwarted. Thanks to the work of the Ljubljana School we can understand the significance of what follows. As Mladen Dolar observes, when we cannot see, distance collapses:

\footnotetext{
The ears have no lids, as Lacan never tires of repeating; they cannot be closed, one is constantly exposed, no distance to sound can be maintained. There is a stark opposition between the visible and the audible: the visible world presents relative stability, permanence, distinctiveness, and a location at a distance; the audible presents fluidity, passing, a certain inchoate, amorphous character, and a lack of distance. (2006, 78-9)
}

Seeing and hearing in synchrony would seem to be anabatic, because it allows us to orient our bodies in space and time; our ears engaging personally with our surroundings while our eyes keep our identity-our distinctness from our surroundings, intact. When the action of the drama moves out of sight as it reaches its crisis, our sense of separation from the fictional events that pass before us may be compromised; audiences may be decentred by their (visual) failure to identify what is happening in the drama, and their (auditory) inability to differentiate from it. This critical, or katabatic, state of affairs, may conjure the genuine states of fear and pity (respectively) which Aristotle associates with Tragedy. 
We can get closer to explicating how this new way of looking at the ancient dramatic crisis articulates criticality if we investigate the different types of sign produced by each side of the skene. This will allow me to add semiotics to my existing palimpsest of dramatic and philosophical structures. Iconic and symbolic signifiers onstage resemble and substitute for their objects in front of the skene. In contrast, signifiers from backstage index, or make us physically contiguous with their objects. Indices are the most primal and urgent of the signs; the indexical signifier literally points to its object as a child who has not yet learned to speak may point. An indexical signifier is like 'a fragment torn away from the object [...] anything which focuses the attention is an index. Anything which startles us is an index'. Indices 'direct the attention to their objects by blind compulsion' (Pierce quoted in Chandler 2002, 41).

The way that the indexical signifier causes such an urgent focus of attention would seem to define crisis. We have seen in Herakles several ways in which the dark side of the skene can activate this state of affairs for audiences; a staged speaker tells us what they 'see' offstage; or someone behind the skene speaks, voices a sound, or makes a noise. Such crises seem to be structured so that we experience them bodily, without mediation. If we compare this with the engagingly televisual (yet separate) mimetic and ekphratic semblances and substitutions on the visible side of the skene, we may come closer to understanding the critical positionality that comes into play for audiences when both sides of the skene are activated. Theoretically, Lykos deserves what he gets, but when we hear his death cries things may not seem so clear-cut. Bodily mediated signifiers, which have to be actively disavowed in authoritarian societies, are privileged in dramatic crisis to confront culturally mediated signifiers and expose the gaps and lacunae that the social mirror fails to reflect. As Critchley puts it, 'the question of theory (spectatorship) and practice, or the gap between theory and practice first opens in theatre and as theatre' $(2017,27)$.

In a dramatic crisis, each side of the skene may impact its audience in structurally very different ways to open an ontological or contemplative gap that sits between metaphor and metonymy. The skene endows us with the clarity and stability of the spectator; but in crisis we pivot between this and the immanent flux of unidentifiable sound. We have seen Plato and Xenophon lead philosophy and history towards an anabatic state of criticality, keen to bring us into the light of logos; while as we shall see the more recent psychoanalytic insights of Freud and Lacan err more towards an emphasis on pathos, crossing the River Charon into the katabatic territory of the underworld, which we associate here with the blind side of the skene.

According to Critchley, tragedy's criticality takes the form of adversarial reasoning whereby we 'audi alteram partem', or hear the other side' $(2017,39)$. But the line of thinking developing here would suggest that the 'other side' we hear in drama is not another reasoned perspective as in a court of law, but the very personal contemplative 'play' that results when eye is split from ear, as it is by the skene, to separate the visible from the invisible. This 'play' seems to conjure the movements between darkness and light, confusion and clarity, the lands of the dead and living that Socrates describes as anabatic and katabatic in his Piraeus story. Plato in turn seems to have adapted these ideas in his cave image of education, but, as Irigiray notes, in a way that represses katabasis, and therefore empathy. When we understand it in this way, the obscene dark side of the skene provides 
audiences with a katabatic shortcut into the corporeal; into a pre-linguistic register that Lacan claims resists symbolic representation altogether to conjure things that society naturally represses:

\begin{abstract}
What we experience as reality is not the 'thing itself', it is always-already symbolised, constituted, structured by symbolic mechanisms - and the problem resides in the fact that symbolization always fails, that it never succeeds in fully 'covering' the real, that it always involves some unsettled, unredeemed symbolic debt. This real (the part of reality that remains non-symbolized) returns in the guise of spectral apparitions. (Lacan qtd. in Žižek 1999, 73-4)
\end{abstract}

Critchley quotes Timocles in one of the earliest recorded responses to tragedy saying something strikingly similar: 'tragedy is described as a parapsuche, an emotional consolation, cooling or coping with life's troubles, but also as a psychagogia, an enthralling persuasion that can also denote the conjuring of souls from another world' $(2017,37)$. Critchley, following Gorgias the Sicilian rhetorician, sees these apparitions in terms of illusion or deception:

\title{
Tragedy, by means of legends and emotions, creates a deception in which the deceiver is more honest than the non-deceiver, and the deceived is wiser than the non-deceived. (Qtd. in Critchley 2017, 36)
}

For Critchley, in watching tragedies we acquire 'wisdom through deception, through an emotionally psychotropic experience' (37). My point here is that deceptive or illusory practices tend to invert or deliberately blur these visual and auditory lands of the living and dead, as in a séance or an act of ventriloquism. Like trompes l'oeil, these practices dress icons and symbols up as indices. When substituting signs masquerade as contiguities in this way, words and bodies seem to swap places; inanimate objects appear to spring uncannily to life, while the living are mesmerised, as if sapped of energy. For Freud this happens when 'a symbol takes on the full function and significance of what it symbolizes' ([1919] 2003, 150). In such situations we may become 'interpellated' (Althusser 1971) or entrapped like Freud's delusional patient President Schreber for whom, as Alenka Zupaničič points out, 'symbolic relations appear as real-like "nerves" and "cosmic rays"' (2008, 161).

The skene, on the other hand, generates anabatic and katabatic 'play'; but it does not create confusion as to which is which to drive us mad: indeed, we could say it drives us sane. In a dramatic crisis both sides of the skene are activated; the ear penetrates it so that audiences may imaginatively inhabit the dramatic situation backstage; but the eye has to rest on its painted side, orienting the viewer firmly in a theatre building. This makes audiences unlikely to believe the fictional situation to be true in a literal sense. But at the same time, it allows us to grasp the realities the fictional situation dramatizes. On the one hand, as we have seen, the auditory register collapses distance so that dramatic events become close to the point of intimacy; on the other hand, because the two sides of the skene play out between the eye and ear, it is as if drama's critical flux takes place quite literally inside our skull. 
In spite of this, the relation between exteriority and imaginative interiority does not blur in drama, as it does in altered or psychotropic states of consciousness such as hallucination and psychosis. According to child psychologist Lev Vygotski, in play a child may stare at a stick yet with the mind's eye see a horse (Minick 2005, 48). Crucially the child experiences a form of double vision because the stick itself never disappears; indeed, it serves as an important boundary protecting children from the horror of not being able to distinguish between fantasy and reality. The skene would seem to serve a similar pivotal function in the performance of tragedies, which is, as Freud points out, 'the form of play and imitation practiced by adults' ([1920] 2006, 143).

Rather than deceiving us by confusing the auditory with the visual, internality with externality, or fantasy with reality, we may be able to see the skene in tragedy as a way of delivering wisdom by maintaining a clear boundary between seeing and what happens to us when we cannot see. This boundary allows us to pivot between Timocles' parapsuche and psychagogia; between the anabatic and katabatic states described by Socrates; between the consoling, yet illusory, clarity and stability of the spectator if we pay attention to its painted side, and a very personal sense of disintegration, reminiscent perhaps of childhood fears of the dark, if we pay attention to its invisible side. Lacan describes how with a mere 'shift of the gaze', the trompe l'oeil can yield the very secrets its illusion conceals:

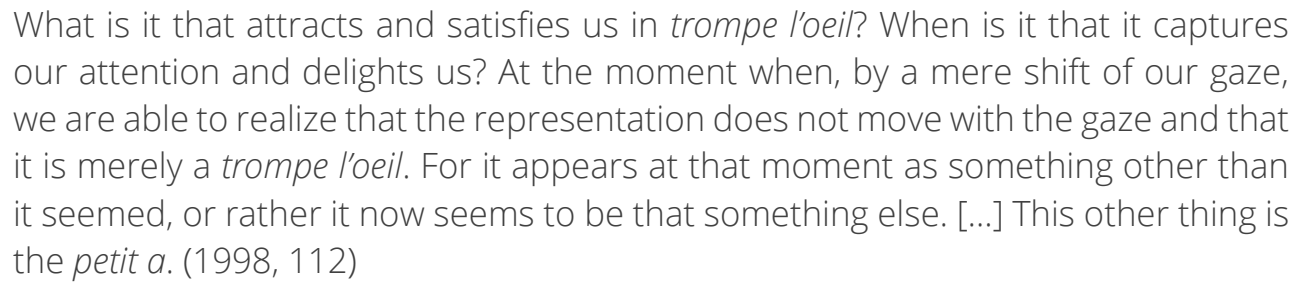

Lacan's petit a famously refers to spectral intimations of a repressed primal scene, and it appears at precisely the moment we stop being mesmerised by illusion and regain our physical agency. For Freud the primal scene refers to the moment of our conception; instead of taking this too literally, we may be able to understand the petit $a$, or primal scene, in the broader terms expressed by Irigaray. As we have seen, Irigaray indicates the need for primal 'intercourse' between the sensible (maternal cave) and the intelligible (paternal 'good'), to instigate the very katabatic movement that Plato's unidirectional anabatic system represses. Rather than an inter-psychic (or social) manoeuvre, this is an intra-psychic (or personal) one; it puts us in touch with ourselves to inaugurate a process of self-creation or autopoiesis. The skene, collapsing the visual stage/world as it does when it invites its audience to enter the inchoate auditory realm in crisis, would seem to short-circuit the gap between the auditorium/'good', and the obscene/cave, bringing the audience and their imagined backstage world into an intimate and fruitful proximity. If we think of the skene as it may have originally existed, as a piece of animal skin, its use in the theatre in this way allows us to live on both sides of our skin. According to the thinking I am developing here we can see this as the critical insight we may gain when we lose the ability to distance ourselves: the insight we may gain from blindness. 
The ancient stage, then, seems to have been endowed by its skene with this capacity for collapse, to disorient audiences alongside the dramatic protagonists, bringing metaphor and metonymy, words and bodies, into radical play. So it is not as if, as Critchley sees it, in watching tragedies we take pleasure 'in spectacles of pain' $(2017,38)$. Do we then take masochistic pleasure in joining the protagonists in their agonies? In his essay 'Beyond the Pleasure Principle' ([1920] 2006), Freud discusses why 'the un-pleasurable nature of an experience does not always render it unusable for play purposes' (142). But he dismisses queasy concerns regarding any sort of pleasure-in-pain to suggest that something more profound than pleasure is at work in enacting painful experiences:

\begin{abstract}
Some economically oriented aesthetic theory may wish to concern itself with these cases and situations where un-pleasure leads ultimately to a gain in pleasure; for our particular purposes, however, they are of no value at all, for they presuppose the dominion of the pleasure principle, and offer no evidence for the prevalence of tendencies beyond the pleasure principle. (143; Freud's emphasis)
\end{abstract}

Freud suggests that mimesis, 'a specific imitative drive', is not the driving force in the performance of tragedies; that something more primal than, and independent of, visual pleasure is at work in plays and playing, whereby we exchange a 'passive role in the actual experience for an active role within the game' (ibid.). To understand this it would seem important to theorise a distinction between pleasure and desire.

It is striking that later in the same essay Freud uses Socrates' terms from the Piraeus story in his efforts to get beyond the notion of pleasure. Freud describes two processes or drives running 'in opposite directions to each other. One that is anabolic or "assimilative"', which he associates with life drives or the pleasure principle; 'and another that is catabolic or "dissimilative"', which he associates with death drives 'beyond' pleasure (178). So while pleasure can be associated with anabasis, for Freud the need to dis-integrate is more primal, and plays and playing are driven by 'the need to restore a prior state' (186, original emphasis). Freud concludes his essay with the observation that 'the pleasure principle seems to be positively subservient to the death drives' (194). Freud may have associated katabasis with death because of the inflection Socrates gave it, but it is a mistake to associate the 'prior state' or the 'death drives' he mentions with morbidity. In a footnote added a year or so later, Freud supposes these two drives to have been dynamically engaged, 'locked in a battle from the very beginning' (191), to produce the play or 'peculiar tension' (194) that motivates both drama and child-play. Lacan later examined these tensions in his 'graph of desire' $(2006,692)$. It is beyond the scope of this paper to explore the graph in detail here, but it may be useful to note that the graph describes two antagonistic movements of desire; an anabolic tendency to condense or unify, assimilating sound and thought to make linguistic communication possible; and a catabolic propensity to displace, opening gaps which expose misrecognitions or hamartia. Thanks to Lacan's rapprochement between psychoanalysis and linguistics we can perhaps identify Freud's 'prior state' less in terms of something moribund or inanimate, and more in terms of the way Euripides crashes down through the communicative gears in Herakles into crisis 
mode; from the lip-synched filmic deception of symbolic and imaginary words and semblances in the proskene; to the pre-linguistic, monadic, undifferentiated register of the 'real'; characterised as we have seen by indices, and conjured by the dark side of the skene.

These ideas are beautifully illustrated earlier in Freud's essay by a game played by his eighteenmonth-old nephew with a cotton reel which had some string tied around it, known as the 'fort/da' (in English, the 'gone/here') game. In this game the child comes to terms with the traumatic comings and goings of his mother, to whom he was 'fondly attached' (140).

\begin{abstract}
Keeping hold of the string, he very skilfully threw the reel over the edge of his curtained cot so that it disappeared inside, all the while making his expressive ' 0 -oo-o' sound, then used the string to pull the reel out of the cot again, but this time greeting its reappearance with a joyful Da! ('Here!'). That then was the entire gamedisappearing and coming back —only the first act of which one normally got to see; and this first act was tirelessly repeated on its own, even though the greater pleasure was undoubtedly attached to the second. (141)
\end{abstract}

The two acts would seem to demonstrate the anabatic and katabatic movements of desire; the 'to be or not to be' of dramatic experience. The more frequently performed upsetting disappearance of the reel whereby (according to Lacan) the reel is 'a small part of the subject that detaches itself from him while still remaining his, still retained' $(1998,62)$. And its' more pleasurable, but less frequently performed, assimilative reunion. Lacanian desire finds release in the muscular spasms of jouissance which are most commonly associated with erotic, or sexual pleasure. But here we join Socrates at the tail end of Plato's Symposium ([c. 385-370 BCE] 2005) (when his own colleagues were too drunk to engage with him), to associate desire with tragedy and comedy; to propose jouissance as the embodied and sometimes surprising release of anabolic (comic), and catabolic (tragic) tension that occurs in theatres; in which like Aristophanes' humans 'cut in half like flatfish' (29), and like Freud's child, we play by splitting and reunifying ourselves; by being as Lacan puts it, 'the fort of the $d a$, and the $d a$ of the fort' $(1998,63)$.

\title{
Revolutionary crises
}

When seen in this way, drama appears to be a quintessentially human activity, hardwired into our playfully desirous ontology, and associated with our most primal, pre-linguistic, drives and releases of energy. The ancient Greeks seem to have used the critical practice of child-play to make autopoiesis available to adults on a grand social scale, and we can understand its revolutionary potential if we focus our attention on the pivot itself as the place that instigates the precipitous splitting process. It is here that logical anabatic and more empathic katabatic states impact on and alter each other to create Irigaray's desired state of embodied cognition, or 'flow', sought after by practice-as-research methodology and performance philosophy, whereby thought and action intersect. Thucydides describes this state of intellectual and physical coherence, some thirty years after the practice of drama had become seriously taken up by the Athenians: 
The Athenians are addicted to innovation, and their designs are characterised by a swiftness alike in conception and execution; you (the Lacedaemonians) have a genius for keeping what you have got, accompanied by a total want of invention, and when forced to act, you never go far enough. (Cited in Castoriadis 1987, 208)

The culture of the ancient Athenians seems to have been envied by people such as the Lacedaemonians, who did not yet practice drama themselves. We can perhaps see the dramatic skene as the physical pivot between the conservative state of 'keeping what you have got', and the desired innovative or autopoietic practices of the Athenians, if we relate it to the way two very different temporalities were represented in the iconography of the time. Chronos is depicted as an old man, while kairos is shown as a youth in full flight. Kairos' hair is shaved at the back and long at the front to show that we must seize the opportunity to catch him bodily as he comes at us headon, before he-and the kairotic moment he represents-passes us by. The nature of this pivotal kairotic instant is emphasised in the image by a set of scales the young man is holding, balanced on a razor's edge. According to Smith (1969), chronos and kairos 'embrace the uniform time of the cosmic system [...] and the time of opportunity or occasion come and gone which marks the significant moments of historical action' (1). Chronos is associated with the predictability delivered by measurable or linear temporality which we connect here with the icons and symbols produced by the skene's visible aspect, reflecting 'what you have got'. Kairos, on the other hand, is associated with the more precarious metonymic contingencies of the site or situation, which we connect here with the dark side of the skene. Comic timing can be said to be kairotic; and as Critchley has it, 'tragedy twists the linear conception of time out of joint' $(2017,40)$. Poised in this way between transcendence and immanence, words and bodies, representation and the real, drama's skene would certainly seem to be designed to help audiences wrangle these temporalities; to shift predictable social paradigms in ways that release the primal, pre-linguistic bursts of comic and tragic energy that may change the lexicon, and so what can be socially understood.

Around 427 BCE the ancients invented a structure at the Theatre of Dionysus that was activated by the plays they staged there to produce for audiences a state of flux, of 'being in crisis': a highly serious, vital, and vitalising social critique. Drama's critical, or 'primal' scenes permitted the sensible to inform the intelligible; so the consolations of representation could be checked out by decentring spectral psychagogia, which operated in connection with the dark side of the skene, in the Lacanian register of the real. In this way the skene took the ancients from states of psychic integration into crises of disintegration and back, to release embodied comic and tragic insights that called their personal and social identities to account. If they could not change the will of heaven, at least they could understand themselves better; and they may have found these two things to be connected because, as Critchley puts it, tragedies 'show us the way in which we collude, seemingly unknowingly, with the calamity that befalls us' $(2017,31)$. Here in the twenty-first century we would seem considerably less likely to look beyond the surface of our screens than the ancient Greeks. It means we are less well in touch with ourselves than they were. But this exploration of their critical play with borders may usefully open up ways in which we could be. 


\section{Works Cited}

Althusser, Louis. 1971. 'Ideology and Ideological State Apparatuses (Notes towards an Investigation)'. In Lenin and Philosophy and Other Essays. Translated by Ben Brewster, 127-86. New York: Monthly Review.

Artaud, Antonin. (1932) 1986. 'The Theatre of Cruelty'. In The Theory of the Modern Stage. Edited by Eric Bentley, 5575. Harmondsworth: Penguin.

Brecht, Bertolt. (1945) 1986. 'The Street Scene'. In The Theory of the Modern Stage. Edited by Eric Bentley, 85-96, Harmondsworth: Penguin.

Critchley, Simon. 2017. 'Tragedy's Philosophy'. In Performing Antagonism. Edited by Tony Fisher and Eve Katsouraki, 25-43. London: Palgrave. https://doi.org/10.1057/978-1-349-95100-0_2

Castoriadis, Cornelius. 1987. The Imaginary Institution of Society. Translated by Kathleen Blamey. Cambridge, MA: MIT Press.

Chandler, Daniel. 2002. Semiotics: The Basics. London: Routledge. https://doi.org/10.4324/9780203166277

Dolar, Mladen. 2006. A Voice and Nothing More. Cambridge, MA: MIT Press.

Euripides. (416BCE) 1997. Herakles. In Plays: 5. Translated by Kenneth McLeish. London: Methuen.

Freud, Sigmund. (1899) 1997. The Interpretation of Dreams. Translated by A. A. Brill. Ware: Wordsworth.

. (1919) 2003. The Uncanny. Translated by David McLintock. London: Penguin.

___. (1920) 2006. 'Beyond the Pleasure Principle'. In The Penguin Freud Reader. Edited by Adam Phillips, 132195. London: Penguin.

Gould, John. 1989. 'Tragedy in Performance'. In Greek Drama. Edited by P. E. Easterling and B.M.W. Knox, 6-29. Cambridge: Cambridge University Press.

Howland, Jacob. 2000. 'Xenophon's Philosophic Odyssey'. American Political Science Review 94 (4): 875-889. https://doi.org/10.2307/2586213

Lacan, Jacques. 1998. The Seminar of Jacques Lacan, Book XI: The Four Fundamental Concepts of Psychoanalysis. Translated by Alan Sheridan. London: Norton.

___. 2006. Écrits. Translated by Bruce Fink. London: Norton.

Minick, N.J. 2005. 'The Development of Vygotski's Thought'. In An Introduction to Vygotski. Edited by Harry Daniels, 32-56. London: Routledge.

Plato. (c. 385-370 BCE) 2005. The Symposium. Translated by Christopher Gill. London: Penguin.

Smith, John. 1969. 'Time, Times, and the Right Time'. The Monist Philosophy of History 53 (1): 1-13.

Whitford, Margaret. 2006. Luce Irigaray: Philosophy in the Feminine. London: Routledge.

Winnington-Ingram, R.P. 1989. 'The Origins of Tragedy'. In Greek Drama. Edited by P. E. Easterling and B.M.W. Knox, 1-6. Cambridge: Cambridge University Press.

Zupančič, Alenka. 2008. The Odd One In. Cambridge, MA: MIT Press.

Žižek, Slavoj. 1999. 'The Spectre of Ideology'. In The Žižek Reader. Edited by Elisabeth and Edmund Wright, 53-86. Oxford: Blackwell.

\section{Biography}

Kate Katafiasz is Senior Lecturer in Drama at Newman University, Birmingham, UK. Her research explores the radicalising effect of drama on the relationship between words and bodies in ancient, educational, and poststructural contexts.

(c) 2018 Kate Katafiasz

Except where otherwise noted, this work is licensed under a Creative Commons Attribution-

NonCommercial-ShareAlike 4.0 International License. 